\title{
Analysis of Generation, of Household Waste and Its Potential Utilization in Darul Imarah subdistrict - Aceh Besar District
}

\author{
Sofia Sofia*, Kartini Kartini, Zubir Zubir \\ Department of Environmental Health, Polytechnic of Health, Ministry of Health, Aceh, Indonesia
}

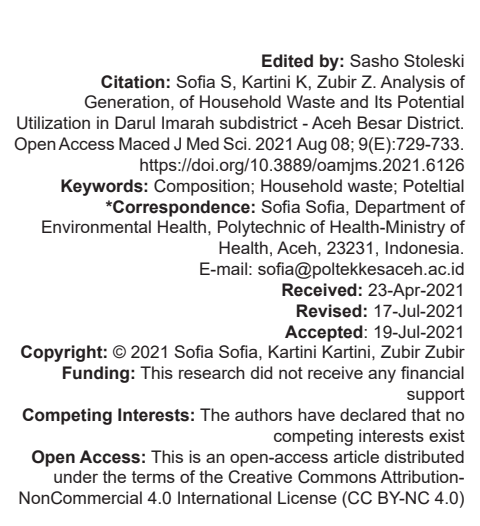

\section{Abstract}

BACKGROUND: Darul Imarah District is one of the largest sub-districts in Aceh Besar, which is very dense and faces a waste problem. The increase in population in the Darul Imarah sub-district has resulted in waste generation.

AIM: Analyzing the generation, composition of household waste and its potential use in Darul Imarah subdistrict Aceh Besar District, Aceh Province.

METHODS: This study used a cross-sectional study design by conducting an initial survey on the generation volume and composition of waste in each house selected as a sample and continued with an experimental study. The research object is solid waste garbage generated from daily activities in the selected sample group households in the Darul Imarah sub-district in the form of primary data from sampling, with a random sampling technique. The number of samples of 100 houses with the respondent's target is housewives. Data analysis was carried out using the t-test difference test to compare the value before being given knowledge about household waste management after being given knowledge.

RESULTS: The study results show differences in the generation and composition of waste before and after being given knowledge about household waste management in Darul Imarah District, Kab. Aceh Besar with a significant (sig.) Of $0.000(0.05)$. The total waste produced before being given knowledge about waste management was $164.6 \mathrm{~kg}$. The composition of the waste consists of plastic waste $(22.9 \mathrm{~kg})$, wet waste $(62.5 \mathrm{~kg})$, dry waste $(37.4 \mathrm{~kg})$ and glass waste $(41.8 \mathrm{~kg})$. After being given knowledge about waste management, there was a reduction in the total waste produced, namely, $131.8 \mathrm{~kg}$. A significant reduction in the amount of waste in the volume of plastic waste $(7.8 \mathrm{~kg})$, wet waste $(48.0 \mathrm{~kg})$, dry waste $(37.3 \mathrm{~kg})$, and glass waste $(38.8 \mathrm{~kg})$. There is a difference in the volume of plastic waste in plastic waste after being given knowledge about household waste management, with the difference between the average before and after is 0.1530 and the difference is between 0.1045 and 0.2015 (95\% confidence interval $[\mathrm{Cl}]$ ). In wet waste, there is a difference in the volume of wet waste after being given knowledge about household waste management with the difference between the before and after averages of 0.1450 and the difference between the differences is between 0.0784 and $0.2116(95 \% \mathrm{Cl})$. In dry waste, there is no difference in the volume of dry waste after being given knowledge about household waste management with an average difference before and after of 0.0020 , and the difference is between -, 0008 and $0.0048(95 \% \mathrm{Cl})$. There is a difference in the volume of glass waste in glass waste after being given knowledge about household waste management with the difference between the before and after an average of 0.0310 and the difference between the differences between 0.0170 and $0.0450(95 \% \mathrm{Cl})$.

CONCLUSION: There are differences in the generation and composition of waste before and after being given knowledge about household waste management in Darul Imarah District, Kab. Aceh Besar with a significant (sig.) of $0.000(0.05)$

\section{Introduction}

In recent times, urbanization, economic development, and an increase in living standards and community lifestyles have led to a sharp growth in municipal waste (MSW), especially in developing countries. It is projected that by 2025 there will be around 4.3 billion people in urban areas, which produces an average of $1.42 \mathrm{~kg}$ of waste per day [1]. Disease burden due to increased exposure to rubbish and waste in lower-middle-income countries and not quite recognizable [2]. All over the world, urban waste generation has been increased significantly over the past few decades, and so has the variety of materials toxic and hazardous waste streams [3]. As a developing country, Indonesia is also inseparable from the problems caused by the impacts and by-products of solid waste management. Based on the amount of waste produced per year, Indonesiails the second-highest country in the world after China, with an amount of waste of 87.2 million tonnes per year [4]. Currently, in Indonesia, only $86.7 \%$ of households (both rural and urban) are served by access to solid waste management, waste that is not segregated is still $81.2 \%$, and only $60 \%$ of existing household waste is transported to the following process [5]. In-Law Number 18 Years In 2008 on Waste Management, the government emphasized that waste management is now a must includes efforts to reduce waste from the source by involving community participation and business people. Improper or inefficient waste disposal methods will result from the 
pollution of air, soil, and groundwater, which will hurt the environment in urban areas and threatens the health of the population [6]. Sewage system waste that is not managed correctly, such as composting, waste treatment, and premise poorly constructed garbage dumps, can cause contamination and, consequently, exposure to the general public [7]. Many research reported on possible solutions to improve sustainable waste management in the country developing, such as organic waste repurchase programs, by composting or biogas [8]. The impact of solid waste on health is varied and possible depending on various factors, including the nature of the waste, duration of exposure, population exposed, and availability of prevention and mitigation interventions [9], [10]. Waste management is a growing challenge in many areas urbanizing rapidly. The number of activities carried out by the community has been given rise to many types of waste. This variety of waste can cause waste generation. If the waste is left unchecked, it will cause problems. Management waste at the household level is one part that needs attention. Management waste will minimize the amount of waste generation that has an impact on the environment. Needconducted a study and analysis of the generation of waste in the household so that the amount of waste generation can be reduced and utilized appropriately. To analyze generation, composition, and potential utilization of household waste in the District of Darul Imarah, Aceh Besar District.

\section{Methods}

This study used a cross-sectional study design by conducting a preliminary survey of waste generation/volume and composition in each house selected as the sample. Furthermore, an experimental study was carried out in the form of empowerment to the community for the potential for waste utilization in the sample group. Then, the giving is done knowledge of household waste management and utilization. Then a second survey was conducted (two) to obtain the volume and composition of waste after being given knowledge about waste management. The research object is solid waste/garbage generated from activities households in the selected sample group in the Darul Imarah subdistrict. The sampling method refers to the sampling method's provisions and measurement of urban waste generation and composition. The research data is in the form of primary data from sampling, with a random sampling technique - the number of samples of 100 houses with the target respondents a housewife. The flow of this research includes preparing tools and materials to calculate the composition and generation of household waste. Go to houses, then provide plastic bags for waste separation. The public is informed about the procedure waste separation. After the garbage has been collected, the enumerator calculates the volume of waste resulting from it. Then, calculate the volume of waste based on its characteristics. The next step is to provide coaching and intervention to the community about waste utilization. Then, the enumerator will do a recalculation of waste generated. Then, evaluate how it is utilized household waste. The data analysis was then done using the T-Test difference test to compare the value before being given knowledge about household waste management after being given knowledge. Furthermore, the data is presented in the form of tables, graphs, and narration.

\section{Results}

Research Location Darul Imarah District is one of the sub-districts in Aceh Besar District with a sub-district area of $24.35 \mathrm{~km} 2$. They are divided into 32 villages, and 117 hamlets. Most of this sub-district is directly adjacent to the capital city of Aceh Province, namely, the city of Banda Aceh. The distance between Darul Imarah District and the capital of Aceh Besar District is $\pm 60 \mathrm{~km}$. In Darul Imarah District, the total population in Aceh Besar District in 2018 was 53,177 people, with 27,030 men and 26,147 women. The number of population, number of families, and average population per family according to kampong in Darul Imarah sub-district can be shown in Table 1. The village's primary source of income in the Darul Imarah subdistrict

Table 1: Distribution of village area, total population, number of families, and average population of households by village in Darul Imarah Subdistrict

\begin{tabular}{|c|c|c|c|c|c|}
\hline No. & Villages & $\begin{array}{l}\text { Size }\left(\mathrm{km}^{2}\right) \\
\left(\mathrm{km}^{2}\right)\end{array}$ & $\begin{array}{l}\text { Population } \\
\text { number }\end{array}$ & $\begin{array}{l}\text { Family } \\
\text { number }\end{array}$ & Averages \\
\hline 1. & Deunong & 2.61 & 1.196 & 284 & 4 \\
\hline 2. & Leu Geu & 0.29 & 358 & 77 & 5 \\
\hline 3. & Lamsiteh & 0.19 & 408 & 100 & 4 \\
\hline 4. & Lampeuneuen & 0.50 & 672 & 140 & 5 \\
\hline 5. & Ulee Tuy & 1.49 & 1.203 & 259 & 5 \\
\hline 6. & Punie & 1.76 & 2.830 & 636 & 5 \\
\hline 7. & Leu Ue & 1.76 & 2.896 & 758 & 4 \\
\hline 8. & Geundring & 2.00 & 617 & 142 & 4 \\
\hline 9. & Pasheu Beutong & 0.99 & 980 & 205 & 5 \\
\hline 10. & Lampasi Engking & 0.68 & 2.096 & 460 & 5 \\
\hline 11. & Jeumpet Ajun & 0.72 & 2.400 & 524 & 5 \\
\hline 12. & Garot & 0.99 & 5.313 & 1.181 & 5 \\
\hline 13. & Gue Gajah & 0.57 & 6.115 & 1.373 & 5 \\
\hline 14. & Ulee Lueng & 0.75 & 854 & 182 & 5 \\
\hline 15. & Lam Bheu & 0.75 & 5.585 & 1.250 & 5 \\
\hline 16. & Kandang & 0.18 & 324 & 74 & 4 \\
\hline 17. & Daroy Kameu & 0.29 & 474 & 122 & 4 \\
\hline 18. & Tingkeum & 0.53 & 1.007 & 222 & 5 \\
\hline 19. & Lamtheun & 0.41 & 1.230 & 286 & 4 \\
\hline 20. & Lamsidaya & 0.46 & 1.036 & 240 & 4 \\
\hline 21. & Kuta Karang & 0.19 & 698 & 140 & 4 \\
\hline 22. & Lamkawee & 0.52 & 710 & 160 & 5 \\
\hline 23. & Lheu Blang & 0.24 & 765 & 185 & 4 \\
\hline 24. & Lagang & 0.23 & 638 & 146 & 4 \\
\hline 25. & Lamblang Manyang & 0.77 & 876 & 191 & 5 \\
\hline 26. & Lamblang Trieng & 0.44 & 788 & 164 & 5 \\
\hline 27. & Payaroh & 0.63 & 932 & 215 & 4 \\
\hline 28. & Lampeuneurut Ujong Blang & 0.27 & 2.467 & 537 & 5 \\
\hline 29. & Lampeunerut Gampong & 0.77 & 816 & 210 & 4 \\
\hline 30. & Lamcot & 0.99 & 2.176 & 424 & 5 \\
\hline 31. & Lamreung & 0.45 & 2.386 & 473 & 5 \\
\hline \multirow[t]{2}{*}{32.} & Bayu & 0.93 & 1.227 & 259 & 5 \\
\hline & Total & 24.35 & 53.177 & 11.619 & 5 \\
\hline
\end{tabular}


is the agriculture and plantation sector (22 kampongs); the rest goes to the manufacturing and trade sectors.

From the Table 1, it can be seen that the total population and area of each village as a whole varies; the area of each village very much determines the population density.

Table 2: Average volume and composition of waste before knowledge of household waste management is given

\begin{tabular}{lllllll}
\hline \multirow{2}{*}{ No. } & Villages & \multicolumn{3}{l}{ Waste $(\mathrm{kg})$} & Total waste $(\mathrm{kg} /$ day) \\
\cline { 3 - 6 } & & Plastics & Wet & dry & Glass & \\
\hline 1. & Lambleut & 3.4 & 8.5 & 2.4 & 3.1 & 17.3 \\
2. & Keutapang & 2.0 & 6.6 & 5.0 & 5.5 & 19.1 \\
3. & Ulee Tui & 5.3 & 12.5 & 10.1 & 13.9 & 41.7 \\
4. & Lagang & 8.6 & 23.8 & 13.5 & 11.9 & 57.7 \\
5. & Daroy Kameu & 3.6 & 11.2 & 6.4 & 7.5 & 28.7 \\
Total waste (kg/day) & 22.9 & 62.5 & 37.4 & 41.8 & 164.6 \\
\hline
\end{tabular}

Meanwhile, the average population in each family is five people. The average volume and composition of waste produced by the community before being given knowledge about household waste management can be shown in Table 2 below.

Table 3: Average volume and composition of waste after knowledge of household waste management is given

\begin{tabular}{lllllll}
\hline No. & Villages & \multicolumn{2}{l}{ Waste $(\mathrm{kg})$} & \multicolumn{2}{l}{ Total waste $(\mathrm{kg} /$ day) } \\
\cline { 3 - 6 } & & Plastics & Wet & dry & Glass & \\
\hline 1. & Lambleut & 1.3 & 6.8 & 2.2 & 2.4 & 12.6 \\
2. & Keutapang & 0.2 & 6.6 & 5.0 & 5.0 & 16.8 \\
3. & Ulee Tui & 1.2 & 8.7 & 10.1 & 13.1 & 33.2 \\
4. & Lagang & 3.2 & 16.8 & 13.5 & 11.2 & 44.6 \\
5. & Daroy Kameu & 1.9 & 9.1 & 6.4 & 7.2 & 24.6 \\
Total Waste (kg/day) & 7.8 & 48.0 & 37.3 & 38.8 & 131.8 \\
\hline
\end{tabular}

The total waste produced before being given knowledge about waste management was $164.6 \mathrm{~kg}$. The composition of the waste consists of plastic waste $(22.9 \mathrm{~kg})$, wet waste $(62.5 \mathrm{~kg})$, dry waste $(37.4 \mathrm{~kg})$, and glass waste $(41.8 \mathrm{~kg})$. Table 3 average volume and composition of waste after knowledge of household waste management is given.

Table 4: Results of the analysis of waste volume difference test before and after knowledge of waste management is given

\begin{tabular}{lllll}
\hline Paired samples statistics & & & & \\
\hline Waste composition & Mean & $\mathrm{N}$ & Std. deviation & Std. error mean \\
\hline Pair 1 & & & & \\
$\quad$ Plastics- before & 0.231 & 100 & 0.2596 & 0.0260 \\
$\quad$ Plastik -After & 0.078 & 100 & 0.0894 & 0.0089 \\
$\begin{array}{l}\text { Pair 2 } \\
\quad \text { Wet -Before }\end{array}$ & 0.627 & 100 & 0.4811 & 0.0481 \\
$\quad$ Wet --After & 0.482 & 100 & 0.4006 & 0.0401 \\
$\begin{array}{l}\text { Pair 3 } \\
\quad \text { Dry -Before }\end{array}$ & 0.377 & 100 & 0.3414 & 0.0341 \\
$\quad$ Dry -After & 0.375 & 100 & 0.3412 & 0.0341 \\
$\begin{array}{l}\text { Pair 4 } \\
\text { Glass-Before }\end{array}$ & 0.701 & 100 & 0.4683 & 0.0468 \\
$\quad$ Glass --After & 0.670 & 100 & 0.4366 & 0.0437 \\
\hline
\end{tabular}

After being given knowledge about waste management, there was a reduction in the total waste produced, namely, as much as $131.8 \mathrm{~kg}$. A significant reduction in the amount of waste in the volume of plastic waste $(7.8 \mathrm{~kg})$, wet waste $(48.0 \mathrm{~kg})$, dry waste $(37.3 \mathrm{~kg})$, and glass waste $(38.8 \mathrm{~kg})$ (Table 4$)$.

Table 5: Relationship before and after being given knowledge about waste management

\begin{tabular}{lllll}
\hline \multicolumn{2}{l}{ Paired samples correlations } & & & \\
\hline Pair & Waste composition & N & Correlation & Sig. \\
\hline Pair 1 & Plastics- before \& After & 100 & .339 & .001 \\
Pair 2 & Wet Before \& After & 100 & .725 & .000 \\
Pair 3 & Dry Before \& After & 100 & .999 & .000 \\
Pair 4 & Glass-Before \& After & 100 & .990 & .000 \\
\hline
\end{tabular}

Based on the data above, it is known that the correlation coefficient value for the type of plastic waste is 0.339 with a significant value (sig.) of $0.001(<0.05)$. Hence, it can be said that there is a difference in the volume of plastic waste produced before and after being given knowledge about household waste management. The correlation coefficient value for the type of wet waste is 0.725 with a significant value (sig.) of $0.000(<0.05)$. Hence, it can be said that there is a difference in the volume of wet waste produced before and after being given knowledge about household waste management. The correlation coefficient value for the type of dry waste is 0.999 with a significant value (sig.) of $0.000(<0.05)$. Hence, it can be said that there is a difference in the volume of dry waste produced before and after being given knowledge about household waste management. The correlation coefficient value for the type of glass waste is 0.990 with a significant value (sig.) of 0.000 $(<0.05)$. Hence it can be said that there is a difference in the volume of broken glass waste produced before and after being given knowledge about household waste management (Table 5).

Table 6: Before being given knowledge about household waste management

\begin{tabular}{llllll}
\hline Paired samples test & \multicolumn{3}{l}{} \\
\hline Pair & Waste composition & Paired differences & \\
\cline { 3 - 6 } & & Mean & $\begin{array}{l}\text { Std. } \\
\text { deviation }\end{array}$ & $\begin{array}{l}\text { Std. error } \\
\text { mean }\end{array}$ & $\begin{array}{l}95 \% \mathrm{Cl} \text { of the } \\
\text { difference }\end{array}$ \\
\cline { 3 - 6 } & & & & Lower \\
\hline Pair 1 & Plastics- before and after & 0.1530 & 0.2443 & 0.0244 & 0.1045 \\
Pair 2 & Wet before and after & 0.1450 & 0.3356 & 0.0336 & 0.0784 \\
Pair 3 & Dry before and after & 0.0020 & 0.0141 & 0.0014 & -0.0008 \\
Pair 4 & Glass-before and after & 0.0310 & 0.0706 & 0.0071 & 0.0170 \\
\hline
\end{tabular}

Based on the results of the table above, it is known that the sig value. The volume of plastic-type waste is $0.000<0.05$, which means a difference in the volume of plastic waste after being given knowledge about household waste management. The difference between the mean before and after is 0.1530 , and the difference is between 0.1045 and 0.2015 (95\% confidence interval $[\mathrm{Cl}])$. Sig value. The volume of wet waste is $0.000<0.05$, so it can be concluded that there is a difference in the volume of wet waste after being given knowledge about household waste management. The difference between the mean before and after is 0.1450 , and the difference is between 0.0784 and $0.2116(95 \% \mathrm{Cl})$. ig value. The volume of dry waste is $0.158>0.05$, so it can be concluded that there is no difference in the volume of dry waste after being given knowledge about household waste management. The average difference before and after is 0.0020 , and the difference is between -, 0008 and $0.0048(95 \% \mathrm{Cl})$. Sig value. The volume of glass waste is $0.000<0.05$, so it can be concluded that there is a difference in the volume of glass waste after being given knowledge about household waste management. The difference between the mean before and after is 0.0310 , and the difference is between 0.0170 and $0.0450(95 \% \mathrm{Cl})$ (Tables 6 and 7). 
Table 7: Paired samples test after being given knowledge about household waste management

\begin{tabular}{|c|c|c|c|c|c|}
\hline \multicolumn{6}{|c|}{ Paired samples test } \\
\hline \multirow[t]{3}{*}{ Pair } & \multirow{3}{*}{ Waste composition } & Paired differences & \multirow[t]{3}{*}{$\mathrm{t}$} & \multirow[t]{3}{*}{ Df } & \multirow{3}{*}{ Sig. (2-tailed) } \\
\hline & & $\begin{array}{l}95 \% \mathrm{Cl} \text { of the } \\
\text { difference }\end{array}$ & & & \\
\hline & & Upper & & & \\
\hline Pair 1 & Plastics- before and after & 0.2015 & 6.263 & 99 & 0.000 \\
\hline Pair 2 & Wet before and after & 0.2116 & 4.321 & z9 & 0.000 \\
\hline Pair 3 & Dry before and after & 0.0048 & 1.421 & 99 & 0.158 \\
\hline Pair 4 & Glass-before and after & 0.0450 & 4.389 & 99 & 0.000 \\
\hline
\end{tabular}

\section{Discussion}

The results showed a decrease in the volume of waste produced before and after the provision of knowledge. Before providing knowledge about management, the volume of waste is $164.6 \mathrm{~kg}$. After being given knowledge about volume management, waste experienced a reduction in waste volume by as much as $131.8 \mathrm{~kg}$. Reduction of the amount of waste which is significant is the volume of plastic waste from the previous $22.9 \mathrm{~kg}$ to $7.8 \mathrm{~kg}$. Result statistical calculations show that the correlation coefficient value for the type of plastic waste is 0.339 with a significant value (sig.) of $0.001(<0.05)$. Hence, it can be said that there is a difference in the volume of plastic waste produced before and after being given knowledge about household waste management. The volume of waste generated by each house in the Darul Imarah sub-district averages $1.9 \mathrm{~kg} /$ day, and this figure is more prominent when viewed from the waste assumption, which is generated each person per day of $0.7 \mathrm{~kg}$. The analysis results at the research location note that there is a reduction in the volume of waste because the community can already understand how to manage household waste appropriately after being given knowledge about waste management system. This community-oriented waste collection has the potential to minimize risks generated by waste to society and specific health risks and vulnerabilities of part scavengers [11].

The composition of the waste generated from the research results varies from food scraps to plastic waste; a recapitulation of the composition of the waste produced consists of plastic waste $(22.9 \mathrm{~kg})$, wet waste $(62.5 \mathrm{~kg})$, dry waste $(37.4 \mathrm{~kg})$, and glass waste (41.8kg). Uncontrolled disposal results in heavy severe metal contamination in water, soil, and plants are essential [12]. Open combustion causes $\mathrm{CO}, \mathrm{CO} 2$, SO, NO, PM 10, and other pollutant emissions that affect the atmosphere [13]. Improper or inefficient waste disposal methods will cause air pollution, land, and groundwater seriously, which will hurt the urban environment and threatens the health of the population [6]. Although MSW itself can negatively influence economic development, MSW recycling has prospects to achieve economic and environmental benefits [14], [15]. Although not yet produce a top product, this society's individual is willing to separate waste generated based on the type and composition. The proper waste separation will affect the volume and generation of waste produced. A study conducted in China stated a role in understanding each group carrying out various innovations and waste classification [16]. In other words, when based on sound knowledge and understanding will influence suitable and appropriate behavior allotment. The community's understanding of waste management has made people willing to separate waste by type. The waste composition is influenced by collection frequency, season, economic conditions, weather, and product packaging. Garbage composition, the most dominant form produced in Indonesia, is organic waste (food waste and scraps plants) by $50 \%$, plastic waste by $15 \%$, and paper by $10 \%$. That household rubbish produced by the community in the Darul Imarah sub-district has the potential to be reprocessed with recycled plastic waste into new products such as grocery bags from plastic packaging, boxes tissue, decorative flowers, ecobricks, and composting. Plastic is a resource that can still be used for a long time and can. Recycling activities can be started with efforts to separate waste from waste-producing sources based on waste components. The process cycle of transportation should also be differentiated, where the wet waste is transported each day to avoid the odor and growth of flies, and dry trash can be transported to trash for a few days because it will not smell.

\section{Conclusion}

There are differences in the generation and composition of waste before and after being given knowledge about household waste management in the Darul Imarah District.

\section{References}

1. Hoornweg D, Perinaz BT. What a Waste: A Global Review of Solid Waste Management. Urban Development Series; Knowledge Papers no. 15. Washington, DC: World Bank; 2012. https://doi.org/10.5822/978-1-61091-756-8_20

2. Landrigan PJ, Wright RO, Cordero JF, Eaton DL, Goldstein BD, Hennig B, et al. The NIEHS superfund research program: 25 Years of translational research for public health. Environ Health Perspect. 2015;123(10):909-18. https://doi.org/10.1289/ ehp. 1409247

PMid:25978799

3. Ojeda-Benítez S, Aguilar-Virgen Q, Taboada-González $\mathrm{P}$, Cruz-Sotelo SE. Household hazardous wastes as a potential source of pollution: A generation study. Waste Manag Res. 2013;31(12):1279-84. https://doi. 


\section{org/10.1177/0734242×13510057}

PMid:24293231

4. Jambeck JR, Geyer R, Wilcox C, Siegler TR, Perryman M, Andrady $\mathrm{A}$, et al. Marine pollution. Plastic waste inputs from land into the ocean. Science. 2015;347(6223):768-71. https:// doi.org/10.1126/science.1260352

PMid:25678662

5. Ariyani SF, Putra HP, Damanhuri E, Sembiring E. Evaluation of waste management in piyungan landfill, Bantul regency, Yogyakarta, Indonesia. MATEC Web Conf. 2019;280:05018. https://doi.org/10.1051/matecconf/201928005018

6. Babayemi JO, Dauda KT. Evaluation of solid waste generation, categories and disposal options in developing countries: A case study of Nigeria. J Appl Sci Environ Manage 2009;13(3):83-8. https://doi.org/10.4314/jasem.v13i3.55370

7. Giusti L. A review of waste management practices and their impact on human health. Waste Manage. 2009;29(8):2227-39. https://doi.org/10.1016/j.wasman.2009.03.028

PMid:19401266

8. Hettiarachchi H, Meegoda JN, Ryu S. Organic waste buyback as a viable method to enhance sustainable municipal solid waste management in developing countries. Int $\mathrm{J}$ Environ Res Public Health. 2018;15(11):2483. https://doi.org/10.3390/ ijerph15112483

PMid:30405058

9. Boadi KO, Kuitunen M. Environmental and health impacts of household solid waste handling and disposal practices in third world cities: The case of the Accra Metropolitan Area, Ghana. J Environ Health. 2005;68(4):32-6.

PMid: 16334095

10. Abd El-Wahab EW, Eassa SM, Lotfi SE, El Masry SA, Shatat HZ, Kotkat AM. Adverse health problems among municipality workers in alexandria (Egypt). Int J Prev Med. 2014;5(5):545-56. https://doi.org/10.1645/15-782

\section{PMid:24932385}

11. Gutberlet J, Baeder AM. Informal recycling and occupationa health in Santo André, Brazil. Int J Environ Health Res. 2008;18(1):1-15. https://doi.org/10.1080/09603120701844258 PMid: 18231943

12. Vongdala N, Tran HD, Xuan TD, Teschke R, Khanh TD. Heavy metal accumulation in water, soil, and plants of municipal solid waste landfill in Vientiane, Laos. Int J Environ Res Public Health. 2018;16(1):22. https://doi.org/10.3390/ijerph16010022 PMid:30577663

13. Wiedinmyer C, Yokelson RJ, Gullett BK. Global emissions of trace gases, particulate matter, and hazardous air pollutants from open burning of domestic waste. Environ Sci Technol. 2014;48(16):9523-30. https://doi.org/10.1021/es502250z PMid:25019173

14. Lu JW, Zhang S, Hai J, Lei M. Status and perspectives of municipal solid waste incineration in China: A comparison with developed regions. Waste Manage. 2017;69:170-86. https://doi. org/10.1016/j.wasman.2017.04.014

PMid:28408280

15. Ogunjuyigbe AS, Ayodele TR, Alao MA. Electricity generation from municipal solid waste in some selected cities of Nigeria: An assessment of feasibility, potential and technologies. Renew Sustain Energy Rev 2017;80:149-62. https://doi.org/10.1016/j. rser.2017.05.177

16. Chen F, Chen H, Wu M, Li S, Long R. Research on the driving mechanism of waste separation behavior: Based on qualitative analysis of chinese urban residents. Int $\mathrm{J}$ Environ Res Public Health. 2019;16(10):1859. https://doi.org/10.3390/ ijerph16101859

PMid:31137780 